\title{
Farmers' knowledge and perception of finger millet blast disease and its control practices in western Kenya
}

Wilton Mbinda ${ }^{1,2^{*}}$ (D) Agnes Kavoo ${ }^{3}$, Fredah Maina ${ }^{4}$, Margaret Odeph ${ }^{5}$, Cecilia Mweu $^{5}$, Naomi Nzilani $^{3}$ and Mathew Ngugi ${ }^{6}$

\begin{abstract}
Background: Finger millet blast disease, caused by Pyricularia oryzae, is a serious constrain of finger millet production which is threatening global food security especially to the resource poor smallholder farmers in arid and semiarid regions. The disease adversely affects finger millet production and consumption due to its wide distribution and destruction in all finger millet growing areas of southern Asia and eastern Africa. Here, we present a study that investigated the occurrence, impact, risk factors and farmers' knowledge and perceptions of finger millet blast in Kenya.

Methods: We surveyed blast disease occurrence and interviewed farmers in Bungoma and Kisii Counties of Kenya during March-April 2019. Data were analysed using SPSS statistical program. Descriptive analysis was done by calculating means, percentages, frequencies, and standard errors. Comparative statistics, chi-square and t-tests, were used to evaluate differences existing among the farm characteristics and socio-demographics and the knowledge and perceptions of blast disease and its management practices.

Results: Our results show that blast disease is prevalent in all surveyed areas and adversely affects the productivity of the crop leading to poor yields. The disease occurrence varied from 92 to $98 \%$, and was significantly higher in the major finger millet growing areas compared to the minor ones. Blast occurrence was associated with rainfall, altitude, planting density, intercropping and other farming practices. In all the surveyed regions, farmers had little knowledge about blast disease identification, its detection and spread. Further, the farmers' awareness of blast disease control was inconsistent with established practices.

Conclusions: Our results show mitigation of finger millet blast disease should aim at improving farmers' adoption of best practices through development of acceptable blast-resistant finger millet varieties, use of sustainable disease management practices, fostering linkages and creating new partnerships in the production-supply chain and maintaining a functional seed system. Findings from this study provide essential insights for effective decision making and management of the disease. This is fundamental to sustainable and secure food and income for finger millet growing farmers in Kenya.
\end{abstract}

Keywords: Blast disease, Pyricularia oryzae, Disease management, Farmers'knowledge, Finger millet, Food security

*Correspondence: wilton.minda@gmail.com

${ }^{1}$ Department of Biochemistry and Biotechnology, Pwani University, Kilifi, Kenya

Full list of author information is available at the end of the article

\section{Introduction}

Finger millet, Eleusine coracana Gaertn., is the most important small millet and a significant subsistence crop in arid and semi-arid regions of eastern Africa and Asia under both rain-feed and irrigated systems 
(Thilakarathna et al. 2015; Onyango et al. 2016). Across Kenya, finger millet, locally known as wimbi (Swahili), plays an important role in agriculture and diets (Mgonja et al. 2007). Finger millet is an important food security crop due to its ability to grow in areas with low rainfall as well as its high nutraceutical value and good storability (Vetriventha et al. 2020). Although the crop has a critical role in safeguarding food security, its productivity remains low with average yields between $500-750 \mathrm{~kg} /$ ha compared to a production potential of $2,500 \mathrm{~kg} / \mathrm{ha}$ (Sankar et al. 2011; Grovermann et al. 2018).

Finger millet productivity is constrained by biotic and abiotic stresses as well as socioeconomic factors. The abiotic stresses are mainly due to rudimentary crop husbandry methods, low soil fertility, drought, small landholdings and poor attitude and understanding of the crop. Biotic stresses include weeds, birds, pests and diseases (Grovermann et al. 2018). Finger millet blast disease caused by the fungus Pyricularia oryzae Cavara (=Magnaporthe oryzae B.C. Couch) is the most destructive finger millet disease that threatens its production worldwide as well as to other economically important cereal crops including rice and wheat (Klaubauf et al. 2014; Chung et al. 2020). The infection process is initiated through conidia attachment to the host surface. The conidia thereafter germinates and forms aspersorium, a structure that facilitates direct penetration into the plant tissues (Pan et al. 2019). Once into the plant cells, the pathogen begins a biotrophic growth process for a short period, and thereafter shifts into a necrotrophic growth stage and produces asexual conidia to propagate to other plant tissues (Fernandez and Orth 2018).

Blast disease affects the leaf, neck and spikes of finger millet, distorting plant growth and development affecting its ability to produce grains. The disease causes average yield losses of $20-50 \%$ and even complete crop loss of finger millet in Kenya (Odeph et al. 2020). To reduce these losses, several disease management methods such as planting resistant varieties, sowing time, intercropping, application of fungicides and biocontrol methods have been recommended but with relative success (Lenné et al. 2007). These disease control methods are either too expensive for poor resource farmers or not effective due to the aggressiveness and plasticity of the pathogen. These measures depend to a great extent on farmers' knowledge and perceptions towards crop protection and the availability, affordability, efficacy and sustainability of disease management methods (Valencia et al. 2015).

Several studies have investigated farmers' perceptions and knowledge of various issues associated with agricultural practices and their findings confirm the importance of sharing information between farmers and researchers (Segura et al., 2004; Valencia et al. 2015; Kansiime et al.
2019). Assessment of farmers' perceptions and knowledge on different subjects can assist to display farmers' attitudes and behaviour towards scientific evidence. It is important to understand what farmers know about finger millet blast disease, their perceptions about yield losses, the disease control methods they use and their perceived effectiveness. The degree of farmers' knowledge and perceptions of blast disease and its associated yield losses when compared with science-driven approaches for integrated disease management merits clarification. Farmers' participation and engagement in the implementation of plant disease control measures are essential for their acceptance and adoption. This study aims to investigate farmers' knowledge and perceptions of finger millet blast disease, its specific control measures and the socio-economic impact of crop losses through a participatory rural appraisal approach. Here, we report the assessment of farmers' perceptions of blast disease, their awareness of the yield losses caused by the disease, and their disease management approaches.

\section{Materials and methods \\ Description of the study areas and site selection}

The study was conducted in western Kenya and included two administrative counties, namely, Bungoma and Kisii each consisting of several sub-counties (Fig. 1). The western region is characterized by humid lower midland climate, with altitudes ranging from 900 to $1800 \mathrm{~m}$ above the sea level and with two rainy seasons: short rains (October-December) and long rains (March-May). The major economic activity for the local population is agriculture and animal husbandry. Purposive sampling was used to study the importance of finger millet production in the study area. In Bungoma County, the sampled subcounties were Bungoma Central, Webuye West, Bungoma South and Webuye East; while in Kisii County, the sampled sub-counties were Kitutu Chache, Bobasi, Nyaribari Masaba, South Mugirango, Bomachoge Borabu and Bomachoge Chache. A total of 139 finger millet producers were identified, 46 in Bungoma and 93 in Kisii counties arbitrarily sampled.

\section{Questionnaire and interviews}

The questionnaire was piloted at two field sites in Kenya (Makueni and Machakos counties) with 9 farmers. Data was collected in June 2019 through a semi-structured questionnaire conducted by trained enumerators after pretesting in one sample county. The questionnaire was uploaded onto the Open Data Kit platform and was used to collect data using smartphones. Interviews were administered in the local language of the community during the face-to-face interplay. The targeted respondent in a household was either the head or spouse, or 


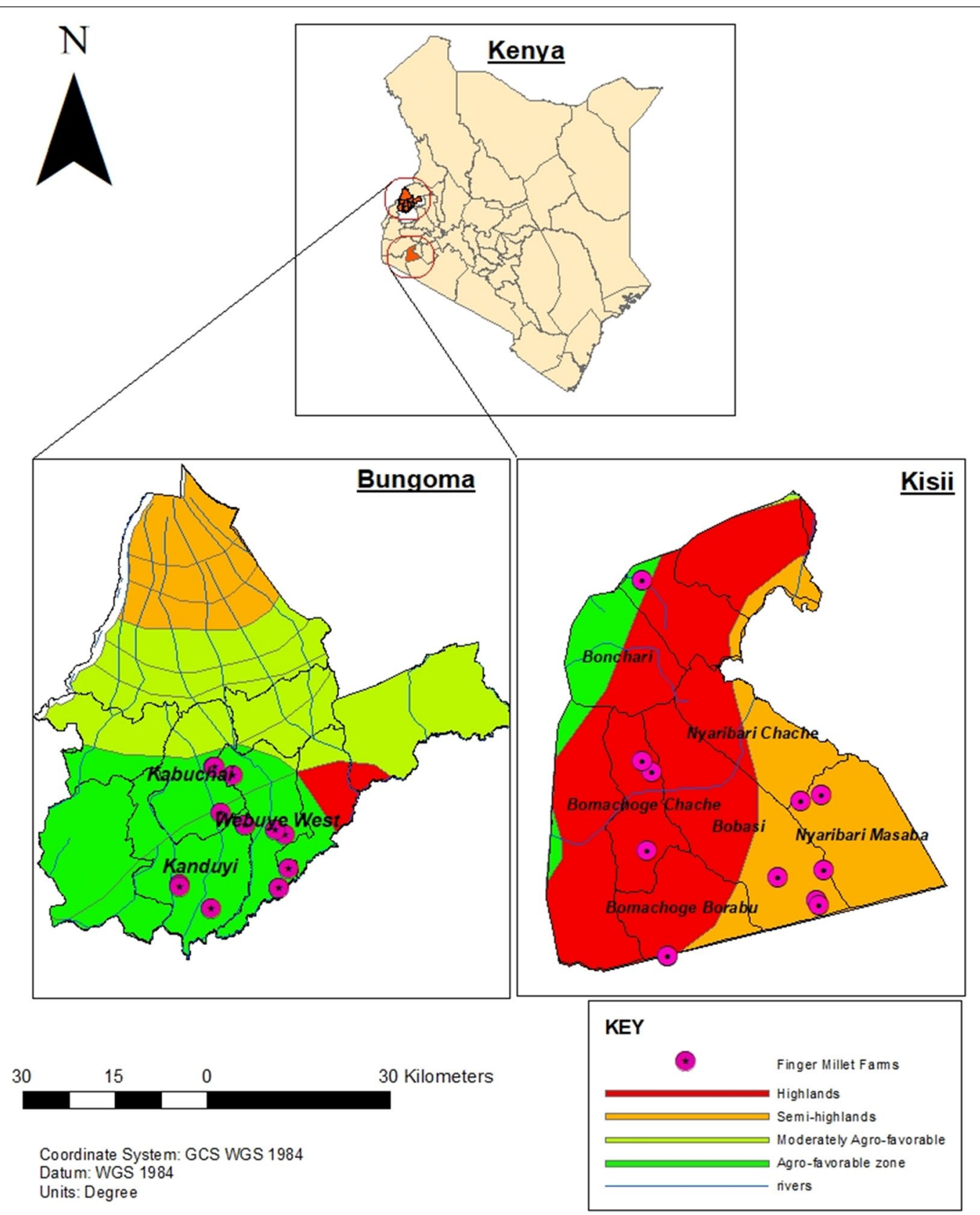

Fig. 1 Maps with the farms surveyed in Bungoma and Kisii counties, Kenya

any household member who had the authority to make farming decisions. Informed consent was sought from the respondents before recording their information and the data were managed according to the General Data Protection Regulation (EU 2016/679). The household survey focused on major crop enterprises and cropping patterns, finger millet variety preferences, management practices, acreage, production, seed selection and storage, seed sources, finger millet utilization and marketing, major finger millet production constraints, finger millet blast (knowledge of transmission and causes, disease occurrence and perceived losses) and sources of technical information.

\section{Statistical analysis}

Collected data were received on an aggregate server in real time, and quality checks were performed to ascertain that the collected data met the standards. After 
completion of the field survey, the final datasets were downloaded from the server and exported to SPSS statistical software for further analyses. Descriptive statistics were performed by calculating means, percentages, frequencies, and standard errors. Comparative statistical methods, chi-square and t-tests, were used to evaluate differences existing among the farm characteristics and socio-demographics and the knowledge and perceptions of blast disease and its management practices. Analysis of variance ANOVA was used for quantitative variables with normal distributions and homogeneous variances. In addition, the farmers' perceptions, the factors that may be linked to finger millet productivity were evaluated, using a factor analysis model of SPSS version 25 in order to understand their effect on finger millet yield. Significance level was set at 0.05 and the means were separated using Tukey's honestly significant difference test.

\section{Results}

\section{Household demographic characteristics}

The household survey results indicated that the sampled finger millet producing households were mainly headed by an adult (90\%) with female heads comprising $57 \%$ of the sample. The household heads had significantly lower education level with only $16 \%$ having gone beyond secondary level of education in Kisii, compared to $37 \%$ in Bungoma. Food crop farming was the most important source of livelihood for $93 \%$ and $67 \%$ of the respondents in Kisii and Bungoma counties respectively (Table 1).

\section{Farm characteristics}

At the time of the study, maize was considered the most important crop produced by $48 \%$ of the respondents, followed by finger millet (47\%) in both Kisii and Bungoma counties (Table 2). Other priority crops included sweet potatoes and beans in Bungoma County and tea, banana and beans in Kisii County. On average, finger millet had been cropped for a significantly longer period in Kisii County (12 years) than in Bungoma County (4 years), where it is a relatively new crop among the sampled households. Finger millet represented more than $25 \%$ of the household income for $75 \%$ of the respondents and more than $50 \%$ for $23 \%$ of the respondents.

\section{Finger millet varieties and seed sources}

Most of the respondents did not know the names of the finger millet varieties they produced. However, they were able to distinguish between traditional varieties and hybrid varieties. The characteristics of finger millet head (whether the spikes were open or closed and the colour of the spikes and the grain) were mainly used to differentiate the varieties. Other attributes included time to maturity and taste. Some respondents

Table 1 Demographic characteristics of sampled finger millet producing household heads in Bungoma and Kisii counties, Kenya

\begin{tabular}{|c|c|c|c|c|c|}
\hline Household head characteristics & Variable measured & $\begin{array}{l}\text { Bungoma (\%) } \\
N=46\end{array}$ & $\begin{array}{l}\text { Kisii } \\
(\%) \\
N=93\end{array}$ & $\begin{array}{l}\text { Overall } \\
(\%) \\
\mathrm{N}=139\end{array}$ & Chi square \\
\hline Age & $\leq 35$ years & 9 & 11 & 10 & $8.61(d f=3)$ \\
\hline Gender & $\%$ Male & 41 & 44 & 43 & \\
\hline Education level & $\%$ Secondary and below & 63 & 84 & 77 & $10.03(\mathrm{df}=4)$ \\
\hline Main source of income/livelihood & $\%$ Food crop farming & 67 & 93 & 84 & $16.2(\mathrm{df}=5)$ \\
\hline
\end{tabular}

Table 2 Farm characteristics of sampled households in Kisii and Bungoma counties, Kenya

\begin{tabular}{|c|c|c|c|c|}
\hline Farm characteristics & Bungoma & Kisii & Overall & ANOVA \\
\hline Average farm size (acres) + & $2.4(0.42)$ & $1.3(0.12)$ & $1.7(0.16)$ & $11.80^{* * *}$ \\
\hline Land tenure, owner with title (\%) & 70 & 83 & 78 & \\
\hline Experience with finger millet (years) + & $4(0.83)$ & $12(0.84)$ & $9(0.70)$ & $33.48^{* * *}$ \\
\hline \multicolumn{5}{|l|}{ Priority crops (\%) } \\
\hline Maize & 65 & 39 & 48 & \\
\hline Finger millet & 30 & 55 & 47 & \\
\hline \multicolumn{5}{|l|}{ Household income from finger millet (\%) } \\
\hline $\begin{array}{l}>25 \% \\
>50 \%\end{array}$ & $\begin{array}{l}70 \\
26\end{array}$ & $\begin{array}{l}77 \\
22\end{array}$ & $\begin{array}{l}75 \\
23\end{array}$ & \\
\hline
\end{tabular}

+ Std error in parenthesis; ${ }^{* * *}=p \leq 0.01$ 


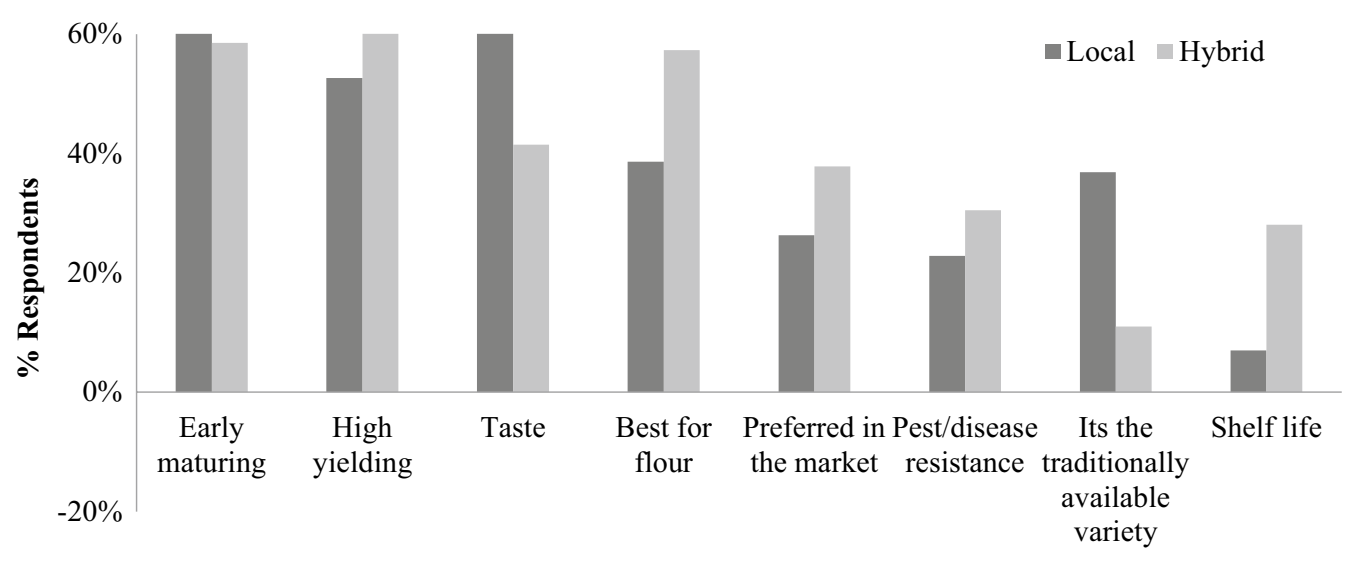

Reason for variety preference

Fig. 2 Reasons for variety preference among finger millet farmers in Bungoma and Kisii counties, Kenya

used both local and hybrid varieties (Fig. 2). On average, $59 \%$ of the respondents in both Kisii and Bungoma counties cultivated mainly hybrid varieties. Among the respondents who planted mainly local finger millet varieties, taste and early maturing (growing period of about 12 weeks) characteristics were the most cited reasons for variety preference with $61 \%$ of the respondents. Among those who preferred hybrid varieties, the most cited characteristics were high yielding (61\%), early maturing (59\%), and best for flour production (57\%). Pest and disease resistance factor was not highly considered for variety preference by the respondents (Fig. 2). Although 59\% of the respondents planted hybrid seeds, seeds were mainly selected from the previous harvest in their own farms or from other farmers (Additional file 1: Fig. S1). Farmers selected the seeds after drying and sorting out the previously harvested grain.

\section{Acreage and production of finger millet}

Finger millet production was practiced on 0.24 ha in the study counties, ranging from 0.04 ha to 1.21 ha. Yield achieved in 2018 was significantly different between the two counties with $826.2 \mathrm{~kg} / \mathrm{ha}$ in Bungoma and $503.9 \mathrm{~kg} / \mathrm{ha}$ in Kisii (Additional file 1: Fig. S2). Prices for finger millet at harvest also differed significantly with Kisii County having a higher price of USD $1.9 / \mathrm{kg}$ compared to USD 1.5/kg in Bungoma County. For $70 \%$ of the time, the producers were able to determine the selling price of finger millet in both counties. Approximately, $83 \%$ of the respondents sold their produce at the market, with $61 \%$ in Bungoma and $94 \%$ in Kisii Country. With the exception of $28 \%$ of respondents in
Bungoma County, the others were able to sell part or all of their finger millet produce.

\section{Constraints to finger millet production}

Yield loss due to finger millet blast disease was identified as the major constraint to finger millet production by $94 \%$ of the respondents. Besides blast disease, the laborious nature of finger millet field practices, especially planting and hand-weeding, were considered as the greatest constraints by $53 \%$ of the respondents. Bird damage was also cited as a setback by $38 \%$ of the respondents. Only $22 \%$ of the respondents indicated that they benefited from training on finger millet production and/or received seeds of improved varieties (Fig. 3).

\section{Awareness and occurrence of finger millet blast}

Our survey results revealed that $94 \%$ of the respondents had finger millet blast in their farms, being considered by them as the most destructive disease of finger millet. The infections of $P$. oryzae were identified as appearance of white to grey-green lesions or spots on leaves, with dark green borders at the initial symptoms while older lesions were elliptical or spindle-shaped with whitish to grey centres and red to brownish or necrotic border. These symptoms coincided with those described the finger millet blast disease. Only $51 \%$ of the respondents were aware of the disease and actually knew the name of the disease (finger millet blast), while the others identified it only when symptoms were described and physical examples were provided (Table 3). The respondents recognized finger millet blast on their crops at different stages of development. In Kisii County, 32\% of the respondents indicated the presence of blast symptoms at vegetative stage (leaf blast) while in Bungoma 93\% of the 


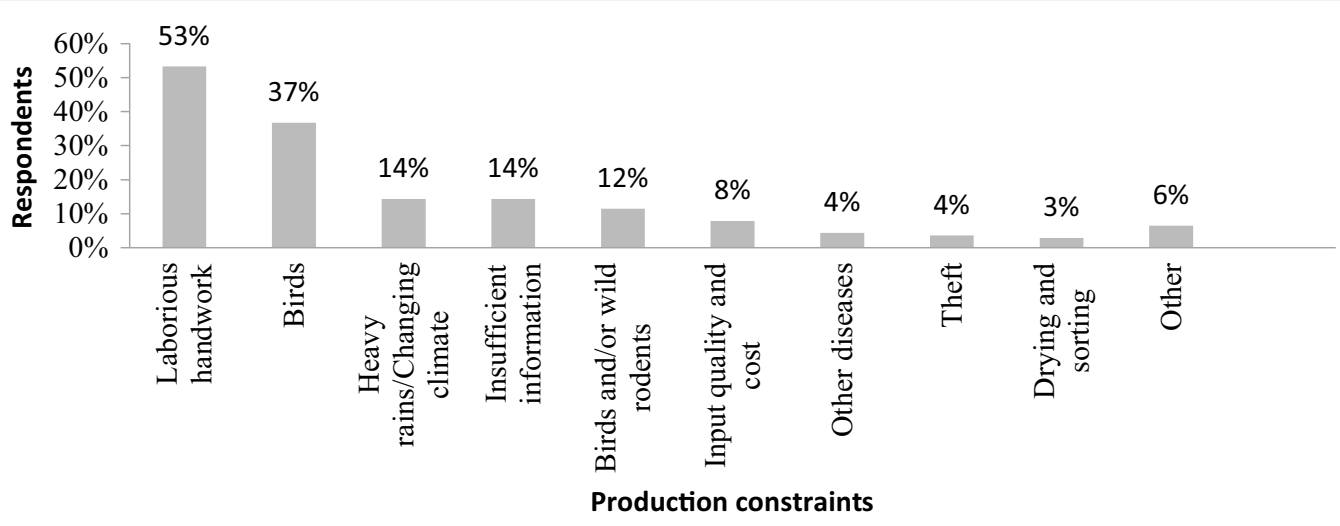

Fig. 3 Other constraints to finger millet production in Bungoma and Kisii counties, Kenya

Table 3 Finger millet blast disease awareness and occurrence in farms in Bungoma and Kisii counties, Kenya

\begin{tabular}{lccll}
\hline Finger millet/Blast & $\begin{array}{l}\text { Bungoma } \\
(\%)\end{array}$ & $\begin{array}{l}\text { Kisii } \\
(\%)\end{array}$ & $\begin{array}{l}\text { Overall } \\
(\%)\end{array}$ & Chi square \\
\hline$>1$ finger miller crop/year & 2 & 76 & 52 & $67.8^{* * *}$ \\
Blast awareness & 26 & 63 & 51 & $17.2^{* * *}$ \\
Blast occurrence & 98 & 92 & 94 & $11.5^{* * *}$ \\
Blast at vegetative stage & 7 & 32 & 24 & \\
Blast at reproductive stage & 93 & 68 & 76 & \\
${ }^{* * *}=p \leq 0.001$ & & & &
\end{tabular}

respondents identified the blast at reproductive or maturity stage (spike/head blast) as shown in Table 3.

\section{Finger millet blast symptoms and seasonality}

When the crop was affected, most of the respondents observed blast symptoms and damage on the head (91\%), the neck (53\%) and leaves (47\%) of the finger millet plants as shown in Fig. 4. Finger millet blast disease was reported to occur throughout the year and being difficult to control by $46 \%$ of respondents in Bungoma
(Additional file 1: Fig. S3). About 53\% of the respondents (44\% in Bungoma and $57 \%$ in Kisii) indicated that finger millet blast was seasonal, occurring regularly during particular seasons of the year, while $30 \%$ of respondents in Kisii Country indicated that the disease was sporadic occurring only in isolated localities and during certain periods. More than half of the respondents (60\%) associated the disease on their farms with sudden and serious outbreaks (i.e., epidemic) while the rest indicated that the disease occurred regularly but at low levels in few foci confined to a particular area (i.e., endemic). Finger millet was cultivated once a year by respondents in Bungoma County, while twice a year by $76 \%$ of the respondents in Kisii Country. Among the latter, 51\% indicated that finger millet blast disease was more severe during the dry season of the year, while 32\% associated higher disease severity to the onset of the wet season. Among the Kisii Country farmers, $71 \%$ indicated that disease severity was dependent on the season (chi square $=3.9^{* *}$ ), being more severe during the second season (later in the year) or when rainfall was greater than usual (Additional file 1: Fig. S3).

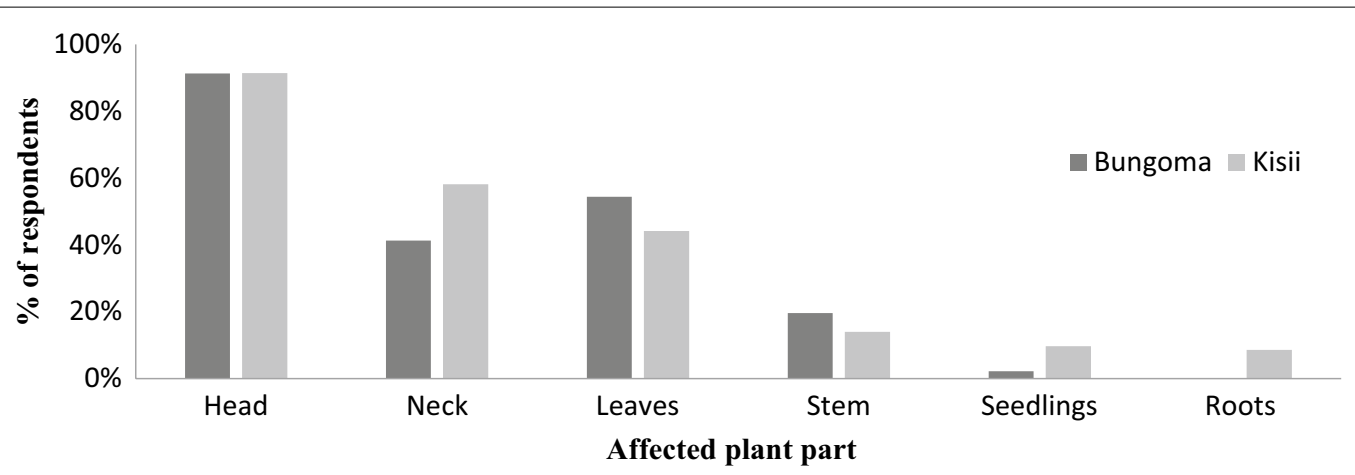

Fig. 4 Farmers response on the plant parts affected by finger millet blast disease in Bungoma and Kisii counties, Kenya 


\section{Perceived means of finger millet blast spread}

Several factors were associated to the spread of finger millet blast disease in both Bungoma and Kisii counties. Up to $67 \%$ of respondents in Bungoma County attributed the spread of finger millet blast disease to the seed or variety grown. However, less than $10 \%$ of the respondents in Kisii County associated the spread of the disease with the seed or variety. In Kisii, the respondents perceived weather patterns (rainfall, wind and changing climate) as the major contributors of increased finger millet blast disease damage (Fig. 5).

\section{Management of finger millet blast}

On average, $22 \%$ of the respondents took no intentional steps to manage blast on finger millet once it appeared on their fields (Additional file 1: Fig. S6). The most common practice and with the highest perceived effectiveness in blast management was hand-weeding (earlier identified as laborious and a major constraint to finger millet production). Other disease control measure reported were uprooting of diseased plants and application of ash. A few farmers indicated they used herbicides (classified as other) for blast management on their fields (Table 4). In the survey, $60 \%$ of the respondents indicated that they used the reported management practice only once in the season. Approximately $60 \%$ of respondents left the infected finger millet stover on the farm while $30 \%$ fed them to livestock. It is important to note that $17 \%$ of respondents in Bungoma burned the infected stover as compared to only $1 \%$ of the respondents in Kisii County (Additional file 1: Fig. S4).
Table 4 Perceived effectiveness of finger millet blast management practices among farmers in Bungoma and Kisii counties, Kenya

\begin{tabular}{llllll}
\hline $\begin{array}{l}\text { Perceived } \\
\text { effectiveness }\end{array}$ & \begin{tabular}{l} 
\% of respondents \\
\cline { 2 - 5 }
\end{tabular} & $\begin{array}{l}\text { No action } \\
\text { Hand- } \\
\text { weeding }\end{array}$ & $\begin{array}{l}\text { Uprooting } \\
\text { infected } \\
\text { plants }\end{array}$ & $\begin{array}{l}\text { Dusting } \\
\text { with ash }\end{array}$ & Other \\
\hline $0-20$ & 22 & 14 & 4 & 4 & \\
$21-40$ & 17 & 5 & 1 & \\
$41-60$ & 22 & & 1 & 1 \\
$61-80$ & 8 & & & 2 \\
$81-100$ & 1 & & & \\
\hline
\end{tabular}

\section{Yield and quality losses associated to finger millet blast} Supplementary material 5 shows the box plots of farmers' finger millet yield before and after the onset of blast disease. Yield losses of $80 \mathrm{~kg} / \mathrm{ha}$ was reported with the onset of blast disease on the farms. The decline in yield was significantly different ranging from $623.77 \mathrm{~kg} / \mathrm{ha}$ to $441.27 \mathrm{~kg} / \mathrm{ha}$, before and after the onset of blast respectively using paired sample $\mathrm{t}$-statistics $\left(\mathrm{t}_{(} \mathrm{t}_{(137)}=4.6^{* * * * *}\right)$. In terms of grain quality, respondents indicated that the grain harvested from diseased finger millet had a different colour (71\%) and different taste (45\%) from the non-diseased grain. At least $22 \%$ of the respondents indicated that other than yield loss, the harvested grain did not change from the expected quality (Additional file 1: Fig. S6).

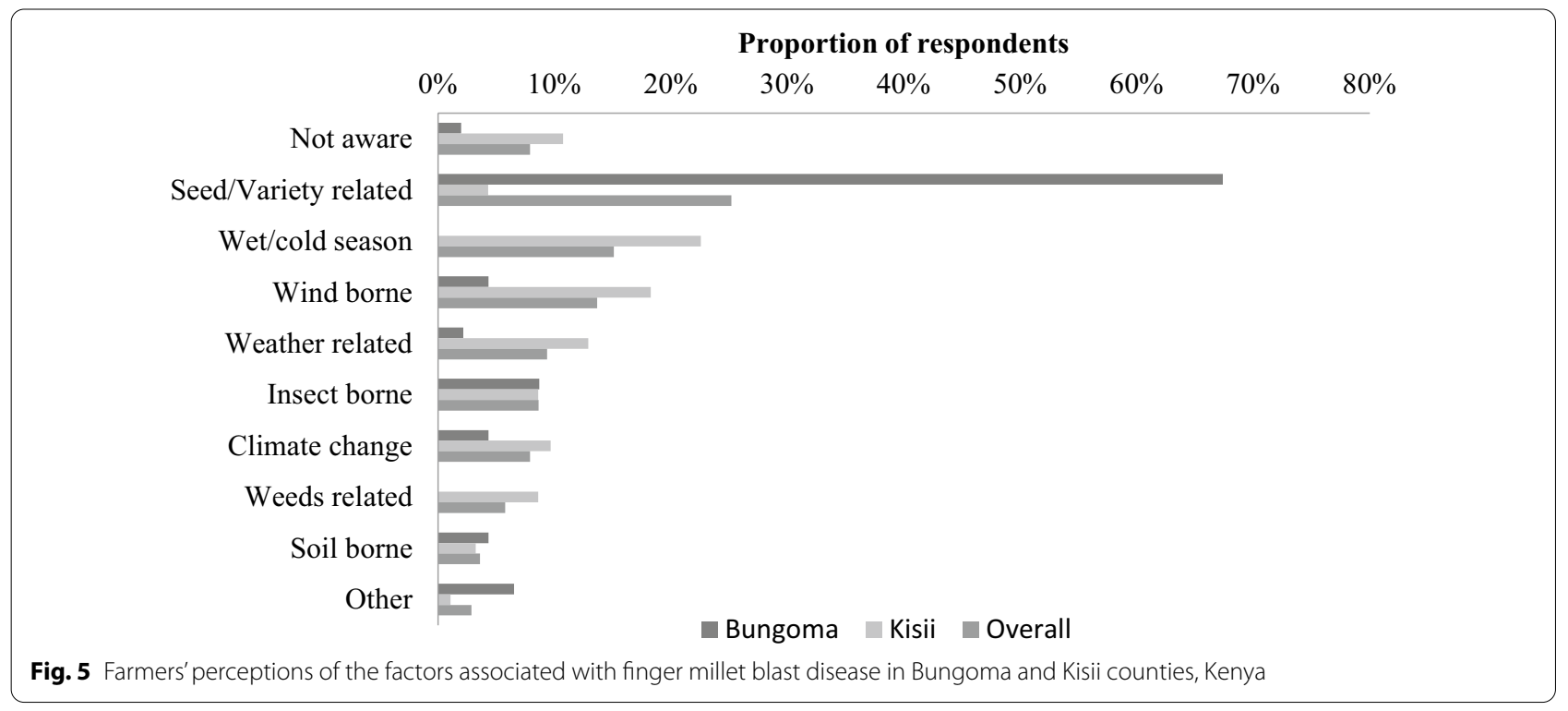




\section{Discussion}

Fungal diseases cause substantial damage to crops globally, posing a serious threat to food security particularly in developing counties. Protection of important crops against these plant diseases in smallholder agriculture is essential for maintenance of ecosystem health and reduction of rural poverty. Previous studies considered blast disease as the most devastating and damaging finger millet disease worldwide (Nagaraja et al. 2007; Manyasa et al. 2019). In this study, we investigated farmers' knowledge and perceptions of finger millet blast disease and its control practices in western Kenya. The structure of smallholder farm households in rural areas are also highly diverse, differing number of family members, head of the family, land area, types and number of livestock, crops grown, and farm management strategies. Understanding the diversity and dynamics of rural households is paramount because global and local influences by population growth, food demand and climate change have a direct and indirect link to plant pests and diseases (Mark van Wijk 2020).

From our findings, the average household size in the surveyed areas of Bungoma and Kisi counties was 6.2, and 6.9 individuals, respectively, which is greater than the country's average household size of 3.9 persons (Kenya National Bureau of Statistics 2019). Adult individuals ( $\geq 18$ years) have decision making power to select the crop and variety, the size of land to cultivate and the choice of farm management practices, which in turn have an impact on finger millet production (Yaméogo et al. 2018). From this study, large family size headed by adult individuals influenced the farming systems that require higher labour requirements and a potential for sustainability of finger millet farming. Households comprising of more than four members were more efficient in finger millet farming compared to those with fewer members, which outsourced their labour requirements or neglected crop husbandry. Our results are consistent with the study by Mrema et al. (2017) who stated that sorghum farming in Tanzania is mostly practiced by large families of 7.1 individuals. Both sorghum and finger millet are labour intensive crops. Household headed by adult women were significantly higher in number compared to those headed by adult men. In Kenya, women play a key role in agriculture, accounting from 42 to $65 \%$ of the agricultural labour needs (Diiro et al. 2018; Sell and Minot 2018). The decision to cultivate finger millet in the study area could therefore have been more influenced by women than men. The low level of education of the household heads reported in the study areas indicates that more than half of the finger millet farmers had a primary education level to understand basic farming practices. For example, a study in Ethiopia by Yemataw et al. (2017) found that the management of Xanthomonas wilt on enset (Ensete ventricosum (Welw.) Cheesman) was highly influenced by the farmers' education level. In this study, pesticide overuse declined with increased levels of education and community-based participatory training. Extension services and researchers are therefore needed as agents of change to inform on the nature and value of new finger millet technologies and agricultural inputs to these communities. Land in the study area is a sensitive matter and the respondents did not wish to disclose the household land size. Nevertheless, from literature, a typical household in the area owns 1.83 ha of land (Berazneva et al. 2018).

Studies indicated that cultivation biodiversity and intercropping farming systems can reduce blast disease in rice experimental fields compared with monoculture (Guang-yu et al. 2016). Such crop diversity creates an ecological setting favourable for the control of blast disease, sustaining high yields. However, it should be noted that the blast pathogen infects over 50 species of cultivated and wild monocot host plants (Gladieux et al. 2018). Care should be taken when creating cultivation biodiversity and intercropping farming systems to avoid alternative hosts of the pathogen. Both mono-cropping and intercropping farming systems were practiced in the study areas in Kenya. The relationship between these farming systems and finger millet blast needs to be established. This survey noticed that a serious decline in finger millet production and productivity associated to its labour requirements and negative reputation among growers towards the crop. In addition, low technological level characterized by minimal use of improved seeds, fertilizers, agrochemicals and low-level machinery was common in finger millet production. Our results are in line with Handschuch and Wollni (2016) who observed that technology adoption was relatively high in maize and rice farming in western Kenya, but less common in finger millet production. Hybrid varieties are common in other cereals such as maize and rice, but finger millet farmers rely mostly on local varieties with low yield potential and highly susceptible to blast disease, resulting in poor returns to farmers' (Vetriventhan et al. 2020).

Disease management is complex and usually limited by the poor knowledge of most farmers about the disease and its control practices. Furthermore, inadequate information about the knowledge level smallholder farmers' on the main diseases which affect their crop can be a major limitation to successfully implement acceptable and effective disease management strategies (AmonArmah et al. 2020). A notable finding from our study is on farmers' perceptions and knowledge in the identification of finger millet blast disease and the recommended management practices. The majority of the respondents were aware that blast disease is a major threat to their 
finger millet production and ranked it as the most devastating constrain. The reasons were that the disease could cause complete yield loss and that there was no available agrochemicals or other disease control management approaches which could be used in practice. This implies that farmers' conceptualization of finger millet plants with symptoms of blast disease does not exactly correspond to the scientific diagnosis. It can therefore be said that farmers are operating on a different paradigm from that of scientists. This was somehow expected given that we found that farmers were growing and managing their finger millet farms with very limited access to extension services. Weed management accounts for up to $50 \%$ of all labour in finger millet farming, making it one of the most expensive activity faced by farmers (Lenné et al. 2007). This problem seems to be solved by the high family members recorded. Moreover, blast also infects weeds such as Eleusine indica, Digitaria spp., Dactyloctenium sp. and Cyperus sp. which normally grow in finger millet farms (Sreenivasprasad et al. 2005). These weeds and others serve as alternative hosts of the fungi. Timely weeding prevents blast propagule dissemination. The hand weeding witnessed in the finger millet farms calls for innovations for improved weed management to reduce the labour cost and the control of millet blast as part of integrated blast control management strategies.

Previous studies (Takan et al. 2004; Odeph et al. 2020) reported blast as the major finger millet disease constraint Kenya. The significance of this fungal disease could be attributed to high occurrence and severity, favourable weather and proximity to a number of alternative hosts making the pathogen inoculum viable for several seasons and various dispersal mechanisms through plants seeds, water, wind, and cultivation materials. On susceptible finger millet varieties and optimum conditions for the disease, foliar symptoms first appears as diamond-shaped lesions which rapidly expand and coalesce affecting entire leaves. When the neck of the plant is infected, the stem parts above the lesion eventually die, leading to heavy yield losses due to the suppression and malformation of grains. The pathogen can also infect the finger millet panicles, resulting in the most destructive phase of blast disease. This phase causes poorly filled, shrivelled and discoloured grains and even the complete failure of grain formation (Takan et al. 2012). In our study, farmers were able to explain the progression of the disease, implying that they had either monitored it for several seasons or they were educated on its phases.

In this study, farmers could not associate the occurrence of blast disease with the different varieties of finger millet. This implies that the landraces and varieties cultivated in the study area were susceptible $P$. oryzae. In the study areas, different finger millet landraces were maintained by the farmers from one harvest to the subsequent one. In general, the interviewed farmers implemented some disease management practices such as crop rotation, phytosanitary measures, good agronomic husbandry, and use of agrochemicals. In the study region, fungicide treatments against $P$. oryzae are not sustainable due to its effects on the environment, the genetic variability of the pathogen and often are too expensive for smallholder farmers (Mbinda and Masaki 2021). Farmers from the study region were not aware of the existence of resistant varieties. The challenge for blast disease resistance in finger millet varieties is that it breaks down after a short period (Manyasa et al. 2019). Nevertheless, planting resistant finger millet varieties still remains as the most effective and sustainable method for controlling blast disease (Oduori 2008). Certainly, an integrated approach encompassing all possible blast control methods will be more effective than just individual measures.

Several finger millet varieties were cultivated in the study areas based in various preferred traits such as adaptability to abiotic and biotic stresses, low input requirements, yield, taste and good cooking quality, high market value and seed availability. Yields in the study regions were very low compared to the average yields of $2500 \mathrm{~kg} / \mathrm{ha}$ obtained under research conditions (Owere 2014). Furthermore, yields of local and hybrid varieties did not differ significantly in the study areas. This may be attributed to low technological level characteristic of the smallholders in traditional cereal production systems. On-station research and field trials have demonstrated that yields can be substantially increased when modern agronomic practices and varieties are used (Handschuch and Wollni 2016; Gimode et al. 2016). The development of finger millet varieties resistant to blast, better adapted to perform in harsh environments and with the traits preferred by farmers will be more easily adopted, as it not currently the case in many parts of Africa (Nkongolo et al. 2008). A top-down approach to cultivar improvement and seed production in many sub-Saharan African countries resulted in varieties that do not meet farmers' preferences or are not well adapted to the local climate or socio-economic conditions. Consequently, very few of these varieties have been adopted by farmers and no major improvements in finger millet yields and blast disease management were achieved in practice.

Form our study, farmers sold their finger miller grains in the local market, getting lower prices than in the supermarkets or major towns. Marketing strategies for finger millet are minimal due to its limited use compared to other major crops such as maize, wheat and rice. These cereals are marketed through government agents who are in charge of their procurement, management, and distribution. These governmental programs include 
regional disease management approaches, beyond the boundaries of individual farms and require all actors in the crop value chain acting synergically and supporting each other. Our study found out that finger millet is produced in an unstructured manner for effective blast disease management and attract investment for large scale farming. A coordinated blast management approach would be more effective if the focus is given to smallholder farmers, who are the bulk of finger millet production, building neighbourhood-based partnerships. For instance, the implementation of a blast disease reporting and management system integrating several finger millet farmers would require formalized structures to assure consistency in data collection and reporting, assessing management actions, and impose sanctions. Moreover, increasing the preference for finger millet consumption would create more opportunities to improve crop productivity and marketability.

The production of improved varieties is usually coordinated by governmental agencies, but this is not case for finger millet landraces or local varieties where seeds are often exchanged between neighbouring farmers or sold in the local markets. From our study, 59\% of the respondents indicated that they planted hybrid seeds which were mainly selected from the previous harvest in their own farms or sourced from other farms. Presently, farmers obtain their seeds mainly from their neighbours, local markets, agricultural input stores as well as research institutions. There is limited information on the public sector engagement in finger millet seed production. Finger millet demand thresholds are too low to raise the interest by private companies to produce seeds of improved blast resistant finger millet varieties (Lenné et al. 2007). Thus, more efforts should be made to boost interactions among researchers, agro-dealers and producers. Finger millet is a self-pollinating crop and this feature greatly restricts chances of cross pollination (Sharma et al. 2018). The concept of farm seed production would therefore play a significant role in increasing access to improved seeds without compromising seed quality. Furthermore, farm seed production system could meet local demand at the proper time and at a fair cost.

\section{Conclusions}

This study illustrated the high prevalence of finger millet blast disease in the surveyed areas in Kenya. To mitigate the effects of finger millet blast disease and increase finger millet productivity in rural areas efforts should be made to enhance farmers' adoption of the best management practices including the use of blastresistant varieties. Likewise, the development and promotion of sound management approaches with farmers are crucial, fostering and creating new partnerships in the production-supply chain, maintaining a functional seed system and achieving an improved and consistent grain quality. These steps would significantly lead to increased yield and boost food security for smallholder farmers in Kenya. Finger millet farmers also need to be trained on symptom detection, disease monitoring and management of finger millet blast because most of them obtained this knowledge directly from their neighbours, friends or relatives. The results of this study will assist to design targeted programs for effective management of blast disease, and ultimately make a significant positive impact on the livelihood of finger millet farmers.

\section{Supplementary Information}

The online version contains supplementary material available at https://doi. org/10.1186/s43170-021-00033-y.

Additional file 1: Fig. S1. Source of finger millet seed sown in the season during the survey in Kisii and Bungoma counties, Kenya. Fig. S2. Yield in 2018 of the preferred finger millet variety in Kisii and Bungoma counties, Kenya. Fig. S3. Finger millet blast occurrence and seasonality in Kisii and Bungoma counties, Kenya. Fig. S4. Management of finger millet stover in Bungoma and Kisii counties, Kenya. Fig. S5. Box plots of finger millet yields before and after the onset of blast in Bungoma and Kisii counties, Kenya. Fig. S6. Effect of finger millet blast on grain quality in Bungoma and Kisii counties, Kenya.

\section{Acknowledgements}

We gratefully acknowledge the County Governments of Busia, Bungoma, for assisting in the study. The authors thank the farmers who participated in this study. Authors are grateful to Institute of Biotechnology Research, Jomo Kenyatta University of Agriculture and Technology for providing facilities for the research. Views expressed herein do not necessarily reflect the official opinion of the funding organization.

\section{Authors' contributions}

AK, WM, MO, CM, NN, FM, MN and conducted the collected the data. FM wrote the draft manuscript. AK and WM reviewed the manuscript, conceptualized the idea. AK, WM, CM, FM, NN, MN, obtained of funding, contributed with experimental design and coordination. All authors agreed on the final appearance of the manuscript after careful review. All authors read and approved the final manuscript.

\section{Funding}

This work was supported financially by the National Research Fund, Kenya, grant NRF/1/MMC/278 and ICGEB grant CRP/KEN18-01.

Availability of data and materials

The datasets used and/or analysed during the current study are available from the corresponding author on request.

\section{Declarations}

Ethics approval and consent to participate Not applicable.

Consent for publication Not applicable.

Competing interests

The authors declare that they have no conflicts of interest. 


\begin{abstract}
Author details
${ }^{1}$ Department of Biochemistry and Biotechnology, Pwani University, Kilif, Kenya. ${ }^{2}$ Pwani University Biosciences Research Centre (PUBReC), Pwani University, Kilif, Kenya. ${ }^{3}$ Deparment of Horticulture, Jomo Kenyatta University of Agriculture and Technology, Juja, Kenya. ${ }^{4}$ Socioeconomics and Policy Development Department, Kenya Agricultural and Livestock Research Organization, Food Crops Research Centre-Kabete, Nairobi, Kenya. ${ }^{5}$ Institute for Biotechnology Research, Jomo Kenyatta University of Agriculture and Technology, Juja, Kenya. ${ }^{6}$ Department of Biochemistry, Microbiology and Biotechnology, Kenyatta University, Nairobi, Kenya.
\end{abstract}

Received: 3 November 2020 Accepted: 10 March 2021

Published online: 29 March 2021

\section{References}

Amon-Armah F, Baah F, Owusu-Ansah F, Adu-Acheampong R, Awudzi GK. Farmers' knowledge of major insect pests and their occurrence in cocoa plantations in Ghana. Int J Pest Manage. 2020. https://doi.org/10.1080/ 09670874.2020.1842551.

Berazneva J, Lee DR, Place F, Jakubson G. Allocation and valuation of smallholder maize residues in Western Kenya. Ecol Econ. 2018;152:172-82. https://doi.org/10.1016/j.ecolecon.2018.05.024.

Chung H, Goh J, Han SS, Roh JH, Kim Y, Heu S, Shim HK, Jeong DG, Kang IJ. Yang JW. Comparative pathogenicity and host ranges of Magnaporthe oryzae and related species. Plant Pathol J 2020;36(4):305. https://doi. org/https://doi.org/10.5423/PPJ.FT.04.2020.0068

Diiro GM, Seymour G, Kassie M, Muricho G, Muriithi BW. Women's empowerment in agriculture and agricultural productivity: Evidence from rural maize farmer households in western Kenya. PLOS ONE. 2018;13(5):e0197995. https://doi.org/10.1371/journal.pone.0197995.

Fernandez J, Orth K. Rise of a cereal killer: the biology of Magnaporthe oryzaebiotrophic growth. Trends Microbiol. 2018;26(7):582-97. https://doi.org/ 10.1016/j.tim.2017.12.007

Gimode D, Odeny DA, de Villiers EP, Wanyonyi S, Dida MM, Mneney EE, Muchugi A, Machuka J, de Villiers SM. Identification of SNP and SSR markers in finger millet using next generation sequencing technologies. PLoS ONE. 2016;11(7):e0159437. https://doi.org/10.1371/journal.pone.0159437.

Gladieux P, Condon B, Ravel S, Soanes D, NunesMaciel JL, et al. Gene flow between divergent cereal- and grass-specific lineages of the rice blast fungus Magnaporthe oryzae. mBio. 2018;9:e01219-e1317. https://doi.org/ 10.1128/mBio.01219-17.

Grovermann C, Umesh KB, Quiédeville S, Kumar BG, Moakes S. The economic reality of underutilised crops for climate resilience, food security and nutrition: assessing finger millet productivity in India. Agriculture. 2018;8(9):131. https://doi.org/10.3390/agriculture8090131.

Guang-yu H, Jie L, Yan S, Yun-yue W, You-yong Z, Bao-rong L. Intercropping of rice varieties increases the efficiency of blast control through reduced disease occurrence and variability. J IntegrAgric. 2016;15:795-802. https://doi.org/10.1016/S2095-3119(15)61055-3.

Handschuch C, Wollni M. Improved production systems for traditional food crops: the case of finger millet in western Kenya. Food Secur. 2016;8(4):783-97. https://doi.org/10.1007/s12571-016-0577-7.

Kansiime MK, Mugambi I, Rwomushana I, Nunda W, Lamontagne-Godwin J, Rware H, Phiri NA, Chipabika G, Ndlovu M, Day R. Farmer perception of fall armyworm (Spodoptera frugiderda JE Smith) and farm-level management practices in Zambia. Pest ManagSci. 2019;75(10):2840-50. https:// doi.org/10.1002/ps.5504.

Kenya National Bureau of Statistics. 2019 Kenya population and housing census. Volume III: distribution of population by age and sex. Pg. 12. December 2019. https://www.knbs.or.ke/?wpdmpro=2019-kenya-popul ation-and-housing-census-volume-iii-distribution-of-population-by-agesex-and-administrative-units

Klaubauf S, Tharreau D, Fournier E, Groenewald JZ, Crous PW, de Vries RP, Lebrun MH. Resolving the polyphyletic nature of Pyricularia (Pyriculariaceae). Stud Mycol. 2014;79:85-120. https://doi.org/10.1016/j.simyco. 2014.09.004.

Lenné JM, Takan JP, Mgonja MA, Manyasa EO, Kaloki P, Wanyera N, Okwadi J, Muthumeenakshi S, Brown AE, Tamale M, Sreenivasaprasad S. Finger millet blast disease management: a key entry point for fighting malnutrition and poverty in East Africa. Outlook Agric. 2007;36:101-8. https://doi.org/ 10.5367/000000007781159994.

Manyasa EO, Tongoona P, Shanahan P, Githiri S, Ojulong H, Njoroge SM. Exploiting genetic diversity for blast disease resistance sources in finger millet (Eleusine coracana). Plant Health Progress. 2019;20(3):180-6. https:// doi.org/10.1094/PHP-11-18-0068-RS.

Mbinda W, Masaki H. Breeding strategies and challenges in the improvement of blast disease resistance in finger millet. A current review. Front Plant Sci. 2021;11:602882. https://doi.org/10.3389/fpls.2020.602882.

Mgonja MA, Lenné JM, Manyasa E, Sreenivasaprasad S. eds. Finger millet blast management in East Africa Creating opportunities for improving production and utilization of finger millet. International Crops Research Institute for the Semi-Arid Tropics. (2007) Patancheru, Andhra Pradesh, India. ISBN 9789290665052

Mrema E, Shimelis H, Laing M, Bucheyeki T. Farmers' perceptions of sorghum production constraints and Striga control practices in semi-arid areas of Tanzania. Int J Pest Manage. 2017;63(2):146-56. https://doi.org/10.1080/ 09670874.2016 .1238115$.

Nagaraja A, Jagadish PS, Ashok EG, Gowda KK. Avoidance of finger millet blast by ideal sowing time and assessment of varietal performance under rain fed production situations in Karnataka. J Mycopathol Res. 2007:45(2):237-40.

Nkongolo KK, Chinthu L, Malusi M, Vokhiwa Z. Participatory variety selection and characterization of sorghum (Sorghum bicolor (L.) Moench) elite accessions from Malawian gene pool using farmer and breeder knowledge. Afr J Agric Res. 2008;3:273-83. https://doi.org/10.5897/AJAR. 9000527

Oduori COA. Breeding investigations of finger millet characteristics including blast disease and striga resistance in Western Kenya. Ph.D. thesis, University of KwaZulu Natal, Durban, South Africa (2008)

Odeph M, Luasi WW, Kavoo A, Mweu C, Ngugi M, Maina F, Nzilani N, Mbinda WM. Occurrence, distribution and severity of finger millet blast caused by Magnaporthe oryzae in Kenya. Afr J Plant Sci. 2020;14(4):139-49. https:// doi.org/10.5897/AJPS2020.1970.

Onyango AO. Finger millet: food security crop in the arid and semi-arid lands (ASALs) of Kenya. World Environ. 2016;6(2):62-70. https://doi.org/10. 5923/j.env.20160602.03.

Owere L, Tongoona P, Derera J, Wanyera N. Farmers' perceptions of finger millet production constraints, varietal preferences and their implications to finger millet breeding in Uganda. J AgricSci. 2014;6(12):126-38. https:// doi.org/10.5539/jas.v6n12p126.

Pan Y, Pan R, Tan L, Zhang Z, Guo M. Pleiotropic roles of O-mannosyltransferaseMoPmt4 in development and pathogenicity of Magnaporthe oryzae. Curr Genet. 2019;65(1):223-39. https://doi.org/10.1007/ s00294-018-0864-2.

Panghal A, Khatkar BS, Yadav DN, Chhikara N. Effect of finger millet on nutritional, rheological, and pasting profile of whole wheat flat bread (chapatti). Cereal Chem. 2019;96(1):86-94. https://doi.org/10.1002/cche.10111.

Sankar GM, Sharma KL, Dhanapal GN, Shankar MA, Mishra PK, Venkateswarlu $B$, Grace JK. Influence of soil and fertilizer nutrients on sustainability of rainfed finger millet yield and soil fertility in semi-arid Alfisols. Commun Soil Sci Plant Anal. 2011;42(12):1462-83. https://doi.org/10.1080/00103 624.2011 .577863

Segura HR, Barrera JF, Morales H, Nazar A. Farmers' perceptions, knowledge, and management of coffee pests and diseases and their natural enemies in Chiapas. Mexico J Econ Entomol. 2004;97(5):1491-9.

Sell M, Minot N. What factors explain women's empowerment? Decisionmaking among small-scale farmers in Uganda. Women's Stud Int Forum. 2018;71:46-55. https://doi.org/10.1016/j.wsif.2018.09.005.

Sharma D, Tiwari A, Sood S, Jamra G, Singh NK, Meher PK, Kumar A. Genome wide association mapping of agro-morphological traits among a diverse collection of finger millet (Eleusine coracana $\mathrm{L}$ ) genotypes using SNP markers. PLoS ONE. 2018;13(8):e0199444. https://doi.org/10.1371/journal. pone.0199444.

Sreenivasaprasad S, Takan JP, Mgonja MA, Manyasa EO, Kaloki P, Wanyera NM, Okwadi, J, Muthumeenakshi S, Brown AE. Lenné JM. Enhancing finger millet production and utilisation in East Africa through improved blast management and stakeholder connectivity'. Enhancing finger millet production and utilisation in East Africa through improved blast management and stakeholder connectivity. Pages 11-22. In: Pathways Out of Poverty, Aspects of Applied Biology 75. D Harris, Jl Richards, P Siverside, 
AF Ward, JR Witcombe, eds. Association of Applied Biologists 2005. Wellesbourne, U.K.

Takan JP. Finger millet blast pathogen diversity and management in East Africa: a summary of project activities and outputs. Int Sorghum Millets Newslett. 2004:45:66-69.

Takan JP, Chipili J, Muthumeenakshi S, Talbot NJ, Manyasa EO, Bandyopadhay R, Sere Y, Nutsugah SK, Talhinhas P, Hossain M, Brown AE, Sreenivasaprasad S. Magnaporthe oryzae populations adapted to finger millet and rice exhibit distinctive patterns of genetic diversity, sexuality and host interaction. MolBiotechnol. 2012;50:145-58. https://doi.org/10. 1007/s12033-011-9429-z.

Thilakarathna MS, Raizada MN. A review of nutrient management studies involving finger millet in the semi-arid tropics of Asia and Africa. Agronomy. 2015;5(3):262-90. https://doi.org/10.3390/agronomy5030262.

Valencia V, West P, Sterling EJ, García-Barrios L, Naeem S. The use of farmers' knowledge in coffee agroforestry management: implications for the conservation of tree biodiversity. Ecosphere. 2015;6(7):1-17. https://doi. org/10.1890/ES14-00428.1.

van Wijk M, Hammond J, Gorman L, Adams S, Ayantunde A, Baines D, Bolliger A, Bosire C, Carpena P, Chesterman S, Chinyophiro A. The rural household multiple indicator survey, data from 13,310 farm households in 21 countries. Sci Data. 2020;7(1):1-9. https://doi.org/10.1038/s41597-020-0388-8. Vetriventhan M, Azevedo VC, Upadhyaya HD, Nirmalakumari A, Kane-Potaka J, Anitha S, Ceasar SA, Muthamilarasan M, Bhat BV, Hariprasanna K, Bellundagi A. Genetic and genomic resources, and breeding for accelerating improvement of small millets: current status and future interventions. Nucleus. 2020. https://doi.org/10.1007/s13237-020-00322-3.

Yaméogo TB, Fonta WM, Wünscher T. Can social capital influence smallholder farmers' climate-change adaptation decisions? Evidence from three semi-arid communities in Burkina Faso, West Africa. SocSci. 2018;7(3):33. https://doi.org/10.3390/socsci7030033.

Yemataw Z, Mekonen A, Chala A, Tesfaye K, Mekonen K, Studholme DJ, Sharma K. Farmers' knowledge and perception of ensetXanthomonas wilt in southern Ethiopia. Agric Food Secur. 2017;6(1):62. https://doi.org/10. 1186/s40066-017-0146-0.

\section{Publisher's Note}

Springer Nature remains neutral with regard to jurisdictional claims in published maps and institutional affiliations.
Ready to submit your research? Choose BMC and benefit from:

- fast, convenient online submission

- thorough peer review by experienced researchers in your field

- rapid publication on acceptance

- support for research data, including large and complex data types

- gold Open Access which fosters wider collaboration and increased citations

- maximum visibility for your research: over $100 \mathrm{M}$ website views per year

At BMC, research is always in progress.

Learn more biomedcentral.com/submissions 